\title{
Recenzja książki Daniela Verby - Le métier d'éducateur de jeunes enfants. Un certain regard sur l'enfant. Nouvelle édition, entièrement actualisée
}

Wychowawca małego dziecka to zawód, który w Polsce od 2013 r. opisany jest w dokumencie charakteryzującym standardy kompetencji zawodowych. Do roku $2011 \mathrm{w}$ żłobkach pracowały opiekunki dziecięce, natomiast na podstawie ustawy z roku 2011 o opiece nad dziećmi w wieku do lat 3 w placówce tej pracuje opiekun. Brakuje regulacji prawnych, na podstawie których „wychowawca małego dziecka” mógłby w toku kształcenia uzyskać uprawnienia oraz dyplom zawierający nazwę tego zawodu. Zainteresowanie publikacją Daniela Verby nie jest przypadkowe, bowiem Autor poświęca ją w całości „narodzinom” zawodu wychowawca małego dziecka we Francji. Procesowi fascynującemu, trudnemu, dynamicznemu, w którym zaznaczyli swój wpływ wybitni pedagodzy, pracownicy w placówkach i rodzice małych dzieci, badacze, prawodawcy.

Na początku zaznaczyć można, że w placówce dla małego dziecka we Francji pracują: pielęgniarka wyspecjalizowana w opiece nad małym dzieckiem do 3 roku życia (puéricultrice) oraz pomoc pielęgniarki (auxiliaire de puéricultrice) - jako pracownicy z przygotowaniem medycznym, a także wychowawca małego dziecka (éducateur de jeunes enfants, EJE) - jako pracownik z przygotowaniem psychologiczno-pedagogicznym.

Książka D. Verby Le métier d'éducateur de jeunes enfants, poświęcona wychowawcy małego dziecka, ukazała się po raz pierwszy w 1993 r. Recenzowane jest jej wydanie z roku 2014, poszerzone, całkowicie zaktualizowane, jak wskazuje Autor. Ta uwaga jest ważna, pokazuje bowiem dzięki temu zabiegowi, że we Francji zachodzą zmiany dotyczące powołania i wykonywania zawodu wychowawcy małego dziecka, przepisów prawnych oraz kształcenia. Dla konstytuowania się tego zawodu przełomowy był Dekret z 2000 r., dzięki któremu przełamano monopol zatrudniania w placówkach dla małych dzieci do 3 roku życia personelu medycznego.

* Uniwersytet Łódzki, Wydział Nauk o Wychowaniu, Katedra Pedagogiki Społecznej. 
Dyrektorem placówki mógł od tego czasu zostać EJE (éducateur de jeunes enfants), którego wykształcenie ma orientację psychologiczno-pedagogiczną. Następne Dekrety zmieniały lub uzupełniały niektóre zagadnienia prawne, na przykład przynosiły poczucie destabilizacji EJE w związku ze zwiększeniem liczby dzieci, którymi zajmowałby się pracownik w placówce, lub obawy, że ze względu na warunki finansowe idea przyjmowania do placówki dziecka i rodziny zmieni się w opiekę (dozór) nad dzieckiem. Niektóre dekrety z czasem zostały uchylone (Verba 2014: 61-63).

W książce wskazać można dwa główne wątki - ten dotyczący historycznych przesłanek powstawania zawodu i możliwości kształcenia oraz prezentację wyników badań wychowawców, która pozwala Autorowi odpowiedzieć na pytanie: co oznaczało być wychowawcą małego dziecka w roku 1993 (pierwsze badania na temat wychowawców zrealizowane przez D. Verbę) oraz w roku 2013 (powtórzone badania na temat wychowawców)? Pierwszy wątek ukazuje etapy kształtowania się zawodu - wychowawca małego dziecka na podstawie analizy okoliczności, które sprzyjały jego wyodrębnianiu się. Autor przedstawia zatem inspirujący wpływ poglądów Johanna Heinricha Pestalozziego oraz Fredricha Fröbela na zawód jardinière d'enfants, którego wykonywania zaprzestano w 2013 r., a który poprzedzał historycznie zawód éducateur de jeunes enfants (tamże: 50).

D. Verba zaznacza, że poglądy Pestalozziego stały się inspiracją dla pedagogicznej aktywności Fröbela. Każdy z tych pedagogów przywoływał w swoich poglądach towarzyszenie dziecku przez wychowawcę zamiast tresury, urabiania poprzez dyscyplinę. Na podstawie analizy wypowiedzi wychowawców na temat źródeł inspirujących dla nich w toku kształcenia do zawodu EJE, Autor wskazuje niedostatek lub nawet brak zainteresowania współczesnych wychowawców historią (zwłaszcza dorobkiem prekursorów). Jednak ów désintérêt nie wynika z ignorancji, jak podkreśla Autor, lecz raczej ukształtował się wyniku przemian, zwłaszcza po roku 1973, kiedy ustanowiono państwowy dyplom EJE, oraz gdy zaczęto odwoływać się do wyników badań psychologicznych na temat małego dziecka jako inspiracji dla namysłu na temat jego oczekiwań w placówce. Warto zauważyć, że oderwanie od dorobku pedagogicznego pokoleń wcześniejszych (przy założeniu ich refleksyjnego odczytania i interpretacji) może zakłócać organizowanie warunków pielęgnowania rozwoju wychowanka, może utrudniać orientowanie działań wychowawcy już przecież wcześniej wyrażonych w postaci koncepcji wychowania, opracowanych przez wybitnych pedagogów i praktyków. Jako przykład można wskazać długi proces przekształcania modelu medycznego organizacji żłobka (rygory medyczne realizowane na rzecz zdrowia i życia dzieci, zwłaszcza po II wojnie światowej) w zapewnieniu warunków opieki nad dzieckiem w placówce na rzecz przesłanek pedagogicznych i psychologicznych.

Drugi wątek w książce pokazuje przemiany zawodu wychowawca małego dziecka - kształcenie, dyplom państwowy, miejsca pracy, obowiązki zawodowe na podstawie analizy wypowiedzi EJE zgromadzonych przez Autora w roku 1993 
oraz 2013. Warto dodać, że w książce Autor podejmuje próbę porównania wyników badań na temat kształtowania się zawodu EJE. Tekst opracowany przez D. Verbę wzbogacony jest obszernymi wypowiedziami, między innymi, uczestników badań realizowanych przez Autora. Wypowiedziom tym warto poświęcić uwagę, bowiem znakomicie uzupełniają informacje dotyczące, na przykład, okoliczności wyboru zawodu, przebiegu kształcenia, charakterystyki aktywności podejmowanej przez wychowawców w polu praktyki, wyobrażeń dotyczących małego dziecka i relacji z nim w placówce, a także trudności w kształtowaniu tożsamości profesjonalnej, refleksji nad działaniem, opracowaniem projektu placówki, współpracy z partnerami w otoczeniu społecznym. Można o przywoływanych wypowiedziach powiedzieć, że tętnią życiem, są sformułowane przez osoby przejęte swoją pracą zawodową, kształtowaniem relacji z dzieckiem i z rodzicami, ujawniają wymiar emocjonalny pracy z małym dzieckiem, przyjemność, radość, wątpliwości i niezgodę. Autor we wprowadzeniu podkreśla znaczenie wypowiedzi uczestników badań dla zaistnienia możliwości, by „zostać dotkniętym” ich refleksją, wyrażonym przez nich punktem widzenia na różnorodne kwestie.

Wychowawca małego dziecka, z uwagi na formalną charakterystykę, określany jest jako pracownik socjalny, specjalista wczesnego dzieciństwa (tamże: 80). We Francji jest to zawód w procesie zmian. Ustanowiony w 1973 r. dyplom państwowy oraz akty normatywne stabilizują jego istnienie, jednak nadal przekształceniu ulegają przepisy prawne dotyczące kształcenia, wzrasta różnorodność miejsc pracy tej kategorii pracowników.

Wychowawca małego dziecka podejmuje pracę w placówkach opieki zbiorowej, na przykład w żłobku (np.: crèche, crèche parentales, halt-garderie, crèche familiale), w różnorodnych strukturach działających na rzecz dziecka i rodziny (np.: ludothèque, médiathèque), w szpitalach, w placówkach edukacyjnych (np.: université populaire de parents, institut médico-éducatifs), w placówkach dla dzieci chorych oraz z dysfunkcjami w rozwoju (tamże: 174-175).

Wychowawcy, którzy uczestniczyli w badaniach realizowanych przez D. Verbę w 1993 r., uznali swoje przygotowanie zawodowe za niewystarczające, zbyt krótkie, niedostatecznie przygotowujące, na przykład do pracy w zespole (między innymi podejmowanie refleksji nad swoją praktyką). Natomiast uczestnicy badań w 2013 r. wyrazili satysfakcję z jakości kształcenia. W 2005 r. czas trwania kształcenia wynosił 3 lata i obejmował 1500 godzin zajęć dydaktycznych oraz 15 miesięcy praktyk (stage) w cyklu kształcenia. Od roku 2013 ośrodki kształcenia EJE przyjęły system ECTS, co umożliwia dalsze kształcenie ich absolwentów na poziomie wyższym (tamże: 82-83). Ośrodki kształcenia również zmieniają się. W związku z decentralizacją kształcenia EJE następuje łączenie szkół w instytuty pracy socjalnej, pojawia się propozycja przekształcenia centrów kształcenia w szkoły wyższe.

Autor pokazuje drogę, jaką przebywa, jak się wydaje, nadal zawód wychowawca małego dziecka we Francji. Kwestia dewaloryzacji zawodu i jego waloryzacji 
poprzez formy kształcenia i dyplom państwowy wciąż jest żywa. Pytanie: czy praca w żłobku jest zawodem, który realizowany jest dzięki kompetencjom niewymagającym długiego uczenia się, znajduje kontrargument w spostrzeżeniu, że powołanie EJE sprzyja określeniu punktu widzenia na dziecko, przywoływaniu określonych wartości w polu praktyki poprzez towarzyszenie dziecku w rozwoju. Opinia społeczna na temat zawodu EJE, bardzo sfeminizowanego (96\% pracowników to kobiety), nadal przywołuje przekonanie, że troska o dzieci jest domeną kobiet i duże nakłady finansowe na kształcenie pracownika, który „zmienia pieluchę”, nie są konieczne (tamże: 111). Autor wskazuje także, iż mimo zmieniającego się stanowiska mężczyzn wobec opieki nad małym dzieckiem - na przykład wyrażenie zadowolenia przez ojca, że jego dziecko ma wychowawcę mężczyznę - mężczyźni wybierający zawód EJE oceniani są pejoratywnie (społeczne tabu), stygmatyzowani (niskie płace), nie podejmują pracy $\mathrm{w}$ zawodzie mimo posiadania dyplomu lub orientują się raczej na stanowisko kierownicze w placówce.

D. Verba wskazuje, że deklaracje na rzecz wyboru zawodu EJE przez kandydatów są niekiedy emocjonalne, naiwne - owo „kocham dzieci” ma wyjaśnić wszystko, tymczasem wydaje się, że to ryzykowna podstawa wyboru zawodu (tamże: 110). Autor przedstawia także inne okoliczności sprzyjające wyborowi zawodu EJE: problemy w rodzinie i chęć znalezienia odpowiedzi na ich temat; religijne oddziaływanie rodziny; przykład wychowawców i nauczycieli w rodzinie; poglądy społeczno-polityczne w rodzinie wspierające oddanie się służbie publicznej.

Ważny proces, któremu podlega charakteryzowany zawód, dotyczy identyfikacji zawodowej. Mimo dynamicznych zmian, Autor podkreśla na podstawie analizy wyników badań, że możliwe jest wskazanie spójnej i podzielanej przez uczestników badań perspektywy na dziecko i towarzyszenie mu $\mathrm{w}$ rozwoju. Ujawnione w wypowiedziach wartości, opisane umiejętności praktyczne są porównywalne i jednoczą wychowawców EJE (tamże: 160). Niektóre terminy syntetycznie opisujące punkt widzenia EJE na wychowanie to: towarzyszenie, obecność wychowawcy - dyskretna i uważna, pobudzanie sił dziecka poprzez tworzenie warunków do uczenia się, zapewnienie pomocy (tej niezbędnej), by dziecko przezwyciężało trudności, wspieranie ciekawości dziecka jako istoty aktywnej w konstruowaniu siebie.

Autor wskazuje filary działania wychowawcy małego dziecka, mianowicie:

- mówienie do dziecka - zwłaszcza wtedy gdy wychowawca wykonuje wobec niego czynności zarezerwowane dla rodziców (np. higiena dotycząca sfery intymnej) - wymaga słów starannie dobranych, prostych fraz, które pomagają traktować dziecko tak, by nie czuło się jak obiekt manipulacji. Mówienie (werbalizacja) do dziecka pomaga również wychowawcy być uważnym, skupionym na dziecku, dostrzegać jego oczekiwania i wyrażać swoją troskę o nie;

- słuchanie dziecka, by poznawać i podejmować wysiłek zrozumienia problemów dziecka oraz adekwatnie na nie odpowiadać; 
- kształtowanie więzi z rodzicami - zwłaszcza podczas pierwszych separacji z dzieckiem pozostającym w placówce, by poznawać dziecko, jego rodzinę i móc ich wspierać;

- wskazywanie możliwych rozwiązań sytuacji zamiast wyciągania sankcji - pozwala uwrażliwiać wychowawcę na trudne zdarzenia w placówce (np. gryzienie), na ich nieoczywistą zazwyczaj przyczynę. Wskazana jest tu wyraźna zachęta dla wychowawcy, by obserwować uważnie dziecko, wspierać je w kształtowaniu relacji z rówieśnikami;

- dodawanie dziecku odwagi dla poznawania siebie i swoich możliwości w trudnych okolicznościach (np. burza);

- podejmowanie działań profilaktycznych we współpracy z rodzicami i pracownikami placówki na rzecz dziecka poprzez obserwowanie, rozmowy, wspólne określanie przyczyn i możliwości rozwiązania problemu;

- opracowanie i realizowanie projektu placówki (projet d'etablissement). Projekt pedagogiczny orientujący codzienną pracę wychowawców został rozwinięty z czasem jako projekt placówki, który z kolei składa się z dwóch elementów - projektu socjalnego i edukacyjnego. Zatem projekt placówki określa jej codzienne zadania poprzez wyartykułowanie orientacji pedagogicznej, rozpoznawanie warunków życia rodzin oraz pracy rodziców, zapewnienie najbardziej oczekiwanych warunków pracy placówki, odpowiadanie na oczekiwania rodzin z danego środowiska lokalnego.

Zakończenie recenzji książki D. Verby, która przedstawia analizę kilkudziesięciu lat kształtowania się zawodu - wychowawca małego dziecka - można syntetycznie sformułować za pomocą kilku słów: szacunek i zachwyt dla małego dziecka oraz wiedza, rzetelna wiedza o nim jako aktywnym uczestniku życia w placówce. Autor bowiem podkreśla, że podczas swoich badań zafrapowany był zadziwiającą, ogromną predyspozycją dziecka do bycia ciekawym i nieustająco gotowym do samodzielnego uczenia się. Różne okoliczności mogą dziecku utrudniać przejawianie tych cech rozwoju. Żłobki stanowią propozycję wspierania rodziny w zabieganiu o rozwój dziecka.

\section{Bibliografia}

Verba D. (2014) Le métier d'éducateur de jeunes enfants. Un certain regard sur l'enfant, Nouvelle édition, entièrement actualisée, Paris, Ed. La Découverte. 